\title{
Bisnis ikan asin dan dampaknya terhadap kesejahteraan masyarakat Sugai Pauh Langsa Barat
}

\author{
Mastura*,Junaidi**, Asyura *** \\ *Fakultas Ekonomi dan Bisnis Islam IAIN Langsa \\ Email:mastura@iainlangsa.ac.id \\ **Fakultas Ekonomi dan Bisnis Islam IAIN Langsa \\ Email: asyurara5@gmail.com \\ ***Fakultas Ekonomi dan Bisnis Islam IAIN Langsa \\ junaidi@iainlangsa.ac.id
}

\begin{abstract}
Abstrak
Bisnis ikan asin merupakan salah satu usaha yang terdapat di Gampong Sungai Pauh Kecamatan Langsa Barat Kota Langsa. Penelitian ini bertujuan untuk mengetahui pendapatan dan kesejahteraan buruh pengolah ikan asin di Gampong Sungai Pauh Kecamatan Langsa Barat. Penelitian ini merupakan penelitian lapangan dengan metode kualitatif deskriptif. Subjek penelitian berjumlah 15 orang. Sumber data yang digunakan adalah data primer dan sekunder yang didapatkan dengan metode pengumpulan data malalui observasi, wawancara, dan dokumentasi. Dengan adanya pengolahan ikan asin, pendapatan buruh pengolah ikan asin sedikit meningkat, sehingga kehidupan buruh pengolah ikan asin ini terbantu secara ekonomi seperti dapat makan tiga kali sehari, membeli pakaian walaupun setahun sekali. Buruh pengolah ikan asin dapat dikategorikan belum sejahtera, namun secara ekonomi buruh pengolah ikan asin sangat terbantu, jika sebelum bekerja di pengolahan ikan asin, buruh pengolah ikan asin hanya dapat makan satu kali sehari namun setelah bekerja di pengolahan ikan asin buruh pengolah ikan asin dapat makan tiga kali sehari, membeli minimal satu stel pakaian, memperbaiki dinding rumah yang sudah rusak.
\end{abstract}

Kata Kunci: Buruh Pengolah Ikan Asin, Pendapatan, Kesejahteraan

\section{Abstract}

The salted fish business is one of the businesses located in Gampong Sungai Pauh, West Langsa District, Langsa City. This study aims to determine the income and welfare of salted fish processing workers in Gampong Sungai Pauh, West Langsa District. This research is a field research with descriptive qualitative methods. The sample consisted of 15 people. Sources of data used are primary and secondary data obtained by data collection methods through observation, interviews, and documentation. With the salted fish processing, salted fish processing workers' income has increased slightly, so that the life of salted fish processing workers is helped economically, such as being able to eat three times a day, buying clothes even once a year. Salted fish processing workers can be categorized as not prosperous, but economically, salted fish processing workers are greatly helped, if before working in salted fish processing, salted fish processing workers can only eat once a day but after working in salted fish processing, salted fish processing workers can eat. three times a day, buy at least one set of clothes, repair the damaged walls of the house.

Keywords: Salted Fish Processing Workers, Income, Welfare 


\section{PENDAHULUAN}

Aceh memiliki luas perairan laut yang luasnya $56.563 \mathrm{Km}$ (tidak termasuk wilayah ZEEI 200 mil) memiliki potensi perikanan laut yang sangat besar baik dalam jumlah maupun jenisnya. Produksi perikanan laut Provinsi Aceh mencapai 532.247 ton mengalami peningkatan sebanyak $5,17 \%$ pada tahun 2018. Salah satu usaha mikro yang tidak asing lagi pada masyarakat Aceh yaitu bisnis ikan asin. Tingginya prospek bisnis ikan asin ini, masyarakat mulai mengembangkan potensi kelautan di setiap daerah Aceh termasuk Langsa. Langsa merupakan salah satu daerah yang kaya akan hasil kelautan. Mudahnya akses mendapatkan hasil laut menjadikan pembisnis ikan asin terus mengembangkan usaha mereka. Perkembangan bisnis ikan asin di Langsa termasuk dalam kategori tinggi.

Berdasarkan penelitian awal peneliti mewawancarai ibu Anisa sebagai pemilik usaha pengolahan ikan asin yang sudah berdiri sejak tahun 2000, Beliau menyampaikan ada beberapa hambatan dalam menjalakan usaha pengolahan ikan asin diantaranya yaitu pada bulan Desember nelayan tidak bisa melaut disebabkan ombak yang tinggi sedangkan dibulan Februari mengalami fase Banjir ikan atau harga ikan dipasar mengalami penurunan harga. Faktor dari fase banjir ikan ini mengakibatkan para pelaku pengusaha pengolahan ikan asin mengalami keterhambatan dalam melakukan produksinya.

Biasanya pengolahan ikan asin hanya mengolah dua kali dalam seminggu, pekerja dalam satu pengolahan ikan asin berkisar 6 sampai dengan 7 orang. Banyak tidaknya pekerja tergantung dengan banyaknya ikan basah yang diperoleh. Pada saat musim banjir ikan harga jual ikan asin bisa menurun dari harga normal. Misalkan ikan talang yang dijual dengan harga Rp. 27.000 per kg disaat normal, namun pada saat banjir ikan harga menurun menjadi Rp. 17.000 per kg. Faktor-faktor tertentu sangat mempengaruhi proses produksi pengolahan ikan asin seperti pada saat musim penghujan ikan asin yang dijemur menjadi berkurang kualitasnya, hal ini juga menyebabkan harga ikan menurun dan sangat berpengaruh terhadap pendapatan produsen ikan asin.

Dalam menjalankan bisnis ikan asin ini, produsen harus bisa melihat situasi dan kondisi. Pada saat nelayan tidak kelaut karena faktor cuaca mereka hanya bisa memilih ikan yang harganya terjangkau. Para pembisnis harus bisa mengatur hasil olahan ikan asinnya kepada pelanggan agar tidak kecewa. Banyaknya permintaan sedangkan hasil produksinya terbatas menjadikan produsen harus rela mendapatkan keuntungan yang relatif kecil. Apalagi produsen dibantu oleh pekerja untuk mengolah ikan asin, produsen harus memperhatikan kesejahteraan pekerja agar selalu ingin di ajak bekerjasama. 
Namun sayangnya, produsen hanya mampu memberikan upah kepada para pekerjanya. Upah tersebut dinilai tidak sesuai dengan jenis pekerjaan yang pekerja lakukan. Produsen hanya memberikan upah Rp.500,- untuk setiap kilonya dalam membelah ikan segar dan selanjutnya di olah menjadi ikan asin. Hal ini tentunya gaji yang diberikan relatif kecil jika dilihat dari pendapatan hasil penjualan ikan asin. Para pekerja juga tidak bisa komplain mengingat para pekerja juga sangat membutuhkan pekerjaan.

Pendapatan adalah sesuatu yang sangat penting dalam setiap perusahaan. Tanpa ada pendapatan mustahil akan didapat penghasilan. Pendapatan adalah penghasilan yang timbul dari aktivitas perusahaan yang biasa dikenal atau disebut penjualan, penghasilan jasa (fees), bunga, dividen, royalti dan sewa (Adawyah, 2008). Dalam bisnis, pendapatan adalah jumlah uang yang diterima oleh perusahaan dari aktivitasnya, kebanyakan dari penjualan produk atau jasa kepada pelanggannya (Junaidi, 2019). Bagi investor pendapatana kurang penting dibanding keuntungan, yang merupakan jumlah uang yang diterima setelah dikurangi pengeluaran. Pertumbuhan pendapatan merupakan indikator penting dari penerimaan pasar dari produk atau jasa perusahaan tersebut.

Jenis-Jenis Pendapatan

pendapatan terbagi menjadi tiga bentuk, yaitu:

1. Pendapatan Ekonomi

Pendapatan ekonomi adalah pendapatan yang diperoleh seseorang atau keluarga yang digunakan untuk memenuhi kebutuhan tanpa mengurangi atau menambah asset bersih. Pendapatan ekonomi meliputi upah, gaji, pendapatan bunga deposito, pendapatan transfer dan lain-lain.

2. Pendapatan Uang

Pendapatan uang adalah sejumlah uang yang diperoleh seseorang atau keluarga pada suatu periode sebagai balas jasa terhadap faktor produksi yang diberikan. Misalnya sewa bangunan, sewa rumah, dan lain sebagainya.

\section{Pendapatan Personal}

Pendapatan personal adalah bagian dari pendapatan nasional sebagai hak individuindividu dalam perekonomian, yang merupakan balas jasa terhadap keikutsertaan individu dalam suatu proses produksi (Manurung, 2017).

Sumber Pendapatan

Rahardja, 2018 menyebutkan bahwa terdapat tiga sumber pendapatan keluarga, 
yaitu:

1. Gaji dan upah

Pendapatan dari gaji dan upah merupakan pendapatan sebagai balas jasa yang diterima seseorang atas kesediaannya menjadi tenaga kerja pada suatu organisasi.

2. Aset produktif

Pendapatan dari asset produktif adalah pendapatan yang diterima oleh seseorang atas asset yang memberikan pemasukan sebagai balas jasa atas penggunaannya.

3. Pendapatan dari Pemerintah

Pendapatan dari pemerintah merupakan penghasilan yang diperoleh seseorang bukan sebagai balas jasa atas input yang diberikan (Rahardja, 2018).

Tingkat Pendapatan

Pendapatan seseorang digolongkan menjadi 4 golongan yaitu:

1. Golongan yang berpenghasilan rendah (low income group), yaitu pendapatan ratarata $\operatorname{Rp} 150.000$

2. Golongan yang berpenghasilan sedang (moderate income group), yaitu pendapatan rata-rata antara Rp. 150.000 - Rp 450.000 per bulan.

3. Golongan berpenghasilan menengah (middle income group), yaitu pendapatan ratarata antara $\operatorname{Rp} 450.000-900.000$

4. Golongan yang berpenghasilan tinggi (high income group), yaitu rata-rata pendapatan perbulan lebih dari Rp. 900.000 (Ustami, 2016).

\section{Kesejahteraan}

Kesejahteraan berasal dari kata "Sejahtera". Sejahtera itu mengandung pengertian dari bahasa sansekreta "Cantera" yang berarti payung. Dalam konteks ini, kesejahteraan yang terkandung dalam arti "Catera" (payung) adalah orang yang sejahtera yaitu orang yang dalam hidupnya bebas dari kemiskinan, kebodohan, ketakutan, atau kekhawatiran sehingga hidupnya aman, tentram, baik lahir maupun batin (Adi Fahrudin, 2012).

Definisi kesejahteraan dalam konsep dunia modern adalah sebuah kondisi dimana seorang dapat memenuhi kebutuhan pokok, baik itu kebutuhan akan makanan, pakaian, tempat tinggal, air minum yang bersih serta kesempatan untuk melanjutkan pendidikan dan memiliki pekerjaan yang memadai yang dapat menunjang kualitas hidupnya sehingga memiliki status sosial yang mengantarkan pada status sosial yang sama terhadap sesama warga lainnya. Kalau menurut HAM, maka definisi kesejahteraan kurang lebih berbunyi 
Jurnal Investasi Islam

Vol. 6 No. 2, Desember $2021: 160-172$

bahwa setiap laki laki ataupun perempuan, pemuda dan anak kecil memiliki hak untuk hidup layak baik dari segi kesehatan, makanan, minuman, perumahan, dan jasa sosial, jika tidak maka hal tersebut telah melanggar HAM. (Basri, 2015).

Faktor-faktor Yang Mempengaruhi Kesejahteraan

a. Faktor Internal Keluarga

Jumlah anggota keluarga pada zaman seperti sekarang init untutan keluarga semakin meningkat tidak hanya cukup dengan kebutuhan primer (sandang, pangan, papan, pendidikan dan sarana pendidikan) tetapi kebutuhan lainnya seperti hiburan, rekreasi, sarana ibadah, sarana untuk transportasi dan lingkungan yang serasi. Tempat Suasana tempat tinggal sangat mempengaruhi kesejahteraan keluarga, keadaan tempat tinggal yang diatur sesuai dengan selera keindahan penghuninya, akan lebih menimbulkan suasana yang tenang dan menggembirakan serta menyejukan hati. Sebaliknya tempat tinggal yang tidak teratur, tidak jarang menimbulkan kebosanan untuk menempatinya.

Keadaan sosial ekonomi keluarga, keadaan sosial dalam keluarga dapat dikatakan baik atau harmonis, bilamana ada hubungan yang baik dan benar-benar didasari ketulusan hati dan rasa kasih saying antara anggota didasari ketulusan hati dan rasa penuh kasih kasih sayang, nampak dengan adanya saling hormatmenghormati, toleransi, bantumembantu dan saling mempercayai.

Keadaan ekonomi keluarga, ekonomi dalam keluarga meliputi keuangan dan sumber-sumber yang dapat meningkatkan taraf hidup anggota keluarga jadi semakin banyak sumber-sumber keuangan/pendapatan yang diterima, maka akan meningkatkan taraf hidup keluarga (Qardahawi, 2001).

\section{b. Faktor Eksternal}

Kesejahteraan keluarga perlu dipelihara dan terus dikembangkan, terjadinya kegoncangan dan ketegangan jiwa diantara anggota keluarga perlu dihindarkan, karena hal ini dapat mengganggu ketentraman dan kenyamanan kehidupan dan kesejahteraan keluarga. Faktor yang dapat mengakibatkan kegoncangan jiwa dan ketentraman batin anggota keluarga yang datangnya dari luar lingkungan keluarga antara lain:

a) Faktor manusia yaitu, iri hati, fitnah, ancaman fisik, pelanggaran norma.

b) Faktor alam bahaya alam, kerusuhan dan berbagai macam virus penyakit.

c) Faktor ekonomi Negara pendapatan tiap penduduk atau income perkapita rendah, inflasi. 
d) Faktor nilai hidup, yaitu sesuatu yang dianggap paling penting dalam hidupnya. Nilai hidup merupakan "konsepsi", artinya gambaran mental yang membedakan individual atau kelompok dalam rangka mencapai sesuatu yang diinginkan.

e) Faktor tujuan hidup yaitu sesuatu yang akan dicapai atau sesuatu yang diperjuangkan agar nilai yang merupakan patokan dapat tercapai dengan demikian tujuan hidup tidak terlepas dari nilai hidup.

f) Faktor standar hidup yaitu tingkatan hidup yang merupakan suatu patokan yang ingin dicapai dalam memenuhi kebutuhan.

Indikator Kesejahteraan

Berikut ini beberapa indikator kesejahteraan antara lain sebagai berikut:

a. Badan Pusat Statistik (BPS)

Menurut BPS (Badan Pusat Statistik), ada 14 kriteria untuk menentukan penggolongan rumah tangga miskin atau sejahtera melalui sebagai beriku: ${ }^{1}$

1) Luas lantai bangunan tempat tinggal kurang dari $8 \mathrm{~m}^{2}$.

2) Jenis lantai bangunan tempat tinggal terbuat dari tanah, bamboo, atau kayu murahan.

3) Jenis dinding tempat tinggal mereka terbuat dari bamboo, rumbia, atau yang berkualitas rendah atau tembok tanpa di plester.

4) Tidak memiliki fasilitas buang air besar sendiri, tetapi bersama-sama dengan rumah tangga lain.

5) Sumber penerangan rumah tangga tidak menggunakan listrik.

6) Sumber air minum berasal dari sumur atau mata ai yang tidak terlindungi seperti sungai atau hujan.

7) Bahan bakar untuk memasak sehari-hari adalah kayu bakar, arang, atau minyak tanah.

8) Hanya mengonsumsi daging, susu, atau ayam satu kali dalam seminggu.

9) Hanya membeli satu stel pakaian baru dalam setahun.

10) Hanya sanggup makan sebanyak satu atau dua kali dalam sehari.

11) Tidak sanggup membayar biaya pengobatan di Puskesmas atau Poliklinik. 
12) Sumber penghasilan kepala rumah tangga adalah petani dengan luas lahan 0,5 ha, buruh tani, nelayan, buruh bangunan, buruh perkebunan atau pekerjaan lainnya dengan pendapatan si bawah Rp 600.000,-- per bulan.

13) Pendidikan tertinggi kepala rumah tangga, tidak sekolah, tidak tamat SD, atau hanya tamat SD.

14) Tidak memiliki tabungan dan atau barang yang mudah dijual dengan nilai Rp 500.000,- sepeti sepeda motor (kredit/non kredit), emas, ternak, kapal motor, atau barang berharga lainnya (Ismai, 2012)

\section{METODE}

Pendekatan dan metode penelitian yang digunakan ini adalah metode kualitatif. Metode penelitian ini dimunculkan karena adanya perubahan dalam memandang realita atau kenyataan serta fenomena atau gejala sosial yang di pandang sebagai sesuatu yang utuh tidak dapat dipisahkan dan penuh makna. Metode kualitatif ini sering disebut sebagai penelitian naturalistic karena penelitian nya dilakukan dalam kondisi yang alamiah (natural setting).Adapun yang menjadi populasi dalam penelitian ini adalah sebanyak 15 orang buruh pengolah ikan asin di Gampong Sungai Pauh Kecamatan Langsa Barat. Metode penentuan sampel yang digunakan dalam penelitian ini adalah metode sampel jenuh. Metode sampel jenuh adalah teknik penentuan sampel bila semua anggota populasi digunakan menjadi sampel. Peneliti mengambil sampel semua dari populasi yaitu sebanyak 15 orang buruh pengolah ikan asin.

Teknik Pengumpulan Data untuk penelitian ini adalah melalui Observasi, Wawancara dan Dokumentasi. Teknik analisis data dalam penelitian ini dilakukan melalui tahapan yaitu; reduksi data, sajian data, penarikan kesimpulan.

\section{HASIL DAN PEMBAHASAN}

\section{Analisis Pendapatan Buruh Pengolah Ikan Asin Di Gampong Sungai Pauh KecamatanLangsa Barat.}

Pendapatan merupakan sumber penghasilan seseorang untuk memenuhi kebutuhan sehari-hari dan sangat penting artinya bagi kelangsungan hidup dan penghidupan seseorang secara langsung maupun tidak langsung. Upah nominal buruh/pekerja adalah rata-rata upah harian yang diterima buruh sebagai balas jasa pekerjaan yang telah dilakukan. 
Upah riil buruh/pekerja menggambarkan daya beli dari pendapatan/upah yang diterima buruh/pekerja. Adapun pendapatan buruh pengolah ikan asin di Gampong Sungai Pauh Kecamatan Langsa Barat dapat dilihat pada tabel berikut:

Tabel 1.1

Pendapatan Buruh Pengolah Ikan Asin

\begin{tabular}{lllll}
\hline No. & Nama & Upah/Kg & $\begin{array}{l}\text { Pendapatan/Hari } \\
\text { Kerja }\end{array}$ & Pendapatan/Bulan \\
\hline 1. & Rohaini & Rp.600 & Rp. 30.000- Rp. 70.000 & Rp.200.000-Rp.600.000 \\
2. & Rahmayani & Rp.600 & Rp. 30.000- Rp. 70.000 & Rp.200.000-Rp.600.000 \\
3. & Sarwati & Rp.600 & Rp. 30.000- Rp. 70.000 & Rp.200.000-Rp.600.000 \\
4. & Raybun & Rp.600 & Rp. 30.000- Rp. 70.000 & Rp.200.000-Rp.600.000 \\
5. & Siti jarika & Rp.500 & Rp. 30.000- Rp. 70.000 & Rp.200.000-Rp.600.000 \\
6. & Nurlela & Rp.800 & Rp. 30.000- Rp. 70.000 & Rp.200.000-Rp.600.000 \\
7. & Nur Ajizah & Rp.600 & Rp. 30.000- Rp. 70.000 & Rp.200.000-Rp.600.000 \\
8. & Nur Aini & Rp.500 & Rp. 30.000- Rp. 70.000 & Rp.200.000-Rp.600.000 \\
9. & Vera Maytarina & Rp.800 & Rp. 30.000- Rp. 70.000 & Rp.200.000-Rp.600.000 \\
10. & Nurmalia & Rp.600 & Rp. 30.000- Rp. 70.000 & Rp.200.000-Rp.600.000 \\
11. & Suparmi & Rp.600 & Rp. 30.000- Rp. 70.000 & Rp.200.000-Rp.600.000 \\
12. & Nursiah & Rp.600 & Rp. 30.000- Rp. 70.000 & Rp.200.000-Rp.600.000 \\
13. & Nurhasanah & Rp.500 & Rp. 30.000- Rp. 70.000 & Rp.200.000-Rp.600.000 \\
14 & Sida & Rp.500 & Rp. 30.000- Rp. 70.000 & Rp.200.000-Rp.600.000 \\
15. & Marleni & Rp.600 & Rp. 30.000- Rp. 70.000 & Rp.200.000-Rp.600.000 \\
\hline
\end{tabular}

Sumber: Wawancara Buruh Pengolah Ikan Asin Gampong Sungai Pauh

Berdasarkan tabel 3.11. diketahui upah per kilogram saat membelah ikan asin yaitu berkisar antara Rp.500 sampai dengan Rp.800. Dari beberapa responden dapat disimpulkan bahwa upah yang diberikan yaitu berkisar Rp. 500 sampai dengan Rp. 800 per kilogramnya, sedangkan banyaknya tidak tentu sesuai dengan banyaknya ikan masuk untuk di olah menjadi ikan asin. Berdasarkan wawancara diatas bersama ibu Siti Jarika bahwa hari kerja tidak tentu biasanya tiga kali dalam seminggu untuk membelah ikan semua bergantung dengan banyaknya ikan yang masuk ke pengolahan ikan. Hal ini dapat menunjukan bahwa pekerjaan hanya bergantung kepada masuk atau tidaknya ikan ke pengolahan. Jika ikan sedikit maka pekerja hanya membelah sedikit ikan sehingga berpengaruh terhadap pendapatan pekerja ikan asin. Dari beberapa hasil wawancara dan tabel diatas dapat disimpulkan bahwa semua responden diberi upah per kilogram berkisar Rp. 500- Rp. 800. Upah yang diberikan kepada buruh pengolah ikan asin berbeda-beda pada setiap usaha pengolahan ikan asin, dalam pendapatan per hari kerja hanya mendapatkan upah berkisar Rp. 30.000-Rp. 70.000, banyaknya upah di berikan tergantung banyaknya ikan yang diolah, faktor tidak masuk ikan juga menjadi pengaruh sedikitnya 
Jurnal Investasi Islam

Vol. 6 No. 2, Desember $2021: 160-172$

upah yang diterima oleh buruh pengolah ikan asin. Pendapatan buruh pengolah ikan asin perbulan berkisar antara Rp.200.000-Rp.600.000, upah per bulan dihitung dari jumlah upah yang diberikan per hari kerja buruh pengolah ikan asin. Pendapatan buruh ikan asin tidak bisa di tentukan secara pasti hal ini dikarenakan faktor masuk ikan dari TPI tidak menentu. Berdasarkan kategori pendapatan menurut BPS, Pendapatan buruh pengolah ikan asin termasuk golongan yang pendapatan rendah, yaitu pendapatan rata-rata kurang dari Rp 1.500.000 per bulan.

\section{Analisis Kesejahteraan Buruh Pengolah Ikan Asin Di Gampong Sungai Pauh Kecamatan Langsa Barat}

Menurut BPS untuk mencapai suatu masyarakat yang sejahtera dapat di ukur melalui 14 indikator, berikut ini adalah hasil jawaban responden mengenai indikator kesejahteraan menurut BPS.

1. Luas lantai bangunan tempat tinggal buruh pengolah ikan asin kurang dari $8 \mathrm{~m}^{2}$ per orang

Dapat diketahui dari hasil wawancara penulis ketika meneliti rumah pekerja ikan asin terdapat 15 responden atau semua responden yang tidak memiliki luas rumah $8 \mathrm{~m}^{2}$. Hal ini dapat dikatakan buruh pengolah ikan asinbelum sejahtera dalam hal tempat tinggal.

2. Jenis lantai tempat tinggal buruh pengolah ikan asin dari tanah/bambu/kayu murahan

Bedasarkan jawaban responden, tidak ada perubahan untuk jenis lantai untuk rumah buruh pengolah ikan asin baik sebelum bekerja pada pengolahan ikan asin maupun sesudah bekerja. Berdasarkan dari ke 15 responden yang di wawancarai mereka mengatakan tidak ada perubahan lantai untuk tempat tinggal mereka dikarenakan memang pendapatan mereka tidak mencukupi untuk perbaikan lantai.

3. Jenis dinding tempat tinggal buruh pengolah ikan asin dari bambu/ rumbia/ kayu berkualitas

Dapat dilihat peneliti ketika meneliti responden, hal ini menunjukkan tidak adanya perubahan selama bekerja pada pengolahan ikan asin. Berdasarkan jawaban dari ke 15 responden yang diwawancarai, semua responden masih berdinding papan. Mereka menuturkan memang tidak ada perubahan dinding rumah mereka yang terbuat dari papan yang tidak berkualitas atau papan yang mudah lapuk dan dan masih berdinding kan tepas di karenakan pendapatan yang mereka dapatkan dari bekerja sebagai buruh pengolah ikan asin tersebut memang ditujukan untuk hal-hal yang lebih pokok seperti kebutuhan makan 
sehari-hari dibandingkan untuk perbaikan rumah menjadi lebih mewah.

4. Tidak memiliki fasilitas buang air besar/ bersama-sama dengan rumah tangga lain.

Dalam hal fasilitas buang air besar, terdapat 14 responden yang memiliki pembuangan air sendiri, sedangkan 1 responden masih menumpang pada pembuangan air milik tetangganya. Berdasarkan dari ke 14 responden yang di wawancarai mereka mengatakan sudah memiliki pembuangan air besar sendiri sejak sebelum bekerja di pengolahan ikan asin dengan menyisihkan hasil usahanya atau dari penghasilan mereka sendiri karena mereka sendiri paham akan pentingnya meningkatkan kesehatan dengan adanya pembuangan sendiri-sendiri dan tidak mengunakan lagi toilet bersama-sama dengan rumah tangga lain.

\section{Sumber penerangan rumah tangga tidak menggunakan listrik}

Dalam hal penerangan, disini semua responden sudah memiliki penerangan rumah dengan menggunakan listrik berdasarkan dari ke 15 responden yang diwawancarai mereka mengatakan sudah memiliki penerangan listrik dirumah mereka, karena mereka sadar akan pentingnya penerangan listrik dirumah mereka untuk fasilitas anak belajar dan untuk kegiatan sehari-hari oleh karena itu mereka mengupayakan untuk memasang listrik dengan menyisihkan pendapatan mereka sedikit demi sedikit untuk memasang listrik sebelum atau sesudah bekerja di pengolahan ikan asin mereka memang sudah memiliki penerangan listrik sendiri.

6. Sumber air minum berasal dari sumur/ mata air tak terlindung / sungai / air hujan

Dalam penggunaan air minum semua responden atau ke 15 responden menjawab menggunakan air PDAM, hal ini menyimpulkan bahwa mereka sanggup dalam pembayaran iuran air dalam setiap bulannya.

7. Bahan bakar untuk memasak sehari-hari adalah kayu bakar/ arang/ minyak tanah

Dalam penggunaan bahan bakar untuk memasak sehari-hari dari semua responden terdapat 15 responden yang memasak sudah menggunakan gas sedari sebelum bekerja di pengolahan ikan asin, mereka dapat menyisihkan uang penghasilan mereka untuk membeli kompor gas. Hal ini menunjukkan adanya perubahan penggunaan kompor dari tradisional kekompor gas karena mereka sudah mampu untuk membeli gas dari pendapatan mereka sendiri dimana tingkat kesejahteraan disini diukur melalui kompor gas.

8. Hanya mengkonsumsi daging/ susu/ telur/ ikan dalam satu kali seminggu

Dalam indikator ini semua responden menjawab adanya perubahan dalam mengkonsumsi daging/ susu/ telur/ ikan dalam satu kali seminggu karena dengan adanya pendapatan dari pekerjaan mereka.Semua responden mengatakan bisa mengganti menu 
Jurnal Investasi Islam

Vol. 6 No. 2, Desember 2021 : 160-172

makanan sehat jika mereka bosan dalam memakan telur atau ikan mereka dapat menggantinya dengan daging sesekali. Hal ini menunjukkan adanya peningkatan dari konsumsi daging/ susu/ telur/ ikan setelah mereka bekerja di pengolahan ikan asin.

9. Hanya membeli satu stel pakaian baru dalam setahun

Dalam pertanyaan ini keseluruhan responden menuturkan sebelum mereka bekerja di pengolahan ikan asin mereka tidak sanggup membeli satu stel pakaian baru dalam setahun, kini setelah mereka bekerja di pengolahan ikan asin mereka mengatakan dapat membeli baju baru untuk anaknya walaupun minimal hanya satu tahun sekali. Hal ini menunjukkan jika adanya perubahan karena setelah bekerja di pengolahan ikan asin mereka mampu memenuhi kebutuhan pokok berupa sandang atau setidaknya membeli pakaian baru dalam kurun waktu satu tahun sekali.

10. Hanya sanggup makan sebanyak satu/ dua kali dalam sehari

Dalam hal ini keseluruhan responden menjawab sebelum atau sesudah bekerja di pengolahan ikan asin mereka sanggup makan sehari 2 kali atau 3 kali, mereka sanggup memenuhi kebutuhan berupa pangan yang sangat dasar walaupun hanya dengan makanan yang sederhana.

11. Tidak sanggup membayar biaya pengobatan dipuskesmas / poliklinik

Dalam hal ini semua responden menjawab sebelum bekerja di pengolahan ikan asin mereka memang sudah sanggup untuk berobat di puskesmas karena berobat dipukesmas memang tidak dipungut biaya/ gratis kecuali di poliklinik jika memang keadaan mendesak mengharuskan mereka berobat kementeri.

12. Sumber penghasilan kepala rumah tangga adalah: petani dengan luas lahan $500 \mathrm{~m}^{2}$, buruh tani, nelayan, buruh bangunan, buruh perkebunan dan atau pekerjaan lainnya dengan pendapatan dibawah Rp. 600.000 ,- per bulan

Dalam hal ini terdapat responden yang hanya berpenghasilan Rp. 200.000-Rp. 600.000 per bulannya. Hanya saja beberapa responden ada pekerjaan sampingan seperti menjual jajan di depan rumah, menyediakan jasa cuci baju, maupun menjahit sehingga pendapatan mereka bisa terbantu.

13. Pendidikan tertinggi kepala rumah tangga tidak sekolah/tidak tamat SD/tamat SD

Dalam hal ini semua responden tidak ada yang mengenyam sekolah di jenjang pendidikan yang lebih tinggi. Kebanyakan responden hanya menyelesaikan pendidikan Sekolah Dasar (SD) dan ada yang tamat SMP dan yang paling tinggi hanya tamatan SMA saja baik sebelum atau sesudah bekerja di pengolahan ikan asin. Hal ini menunjukkan 
tidak adanya perubahan mengenai pendidikan mereka kecuali pada anak-anak mereka nanti.

14. Tidak memiliki tabungan/barang yang mudah dijual dengan minimal Rp.500.000,seperti sepeda motor kredit/ non kredit, emas, ternak, kapal motor, atau barang modal lainnya

Dalam hal ini responden menjawab sebelum atau sesudah bekerja di pengolahan ikan asin mereka tidak mempunyai tabungan sedangkan barang yang bisa dijual seperti kendaraan motor ada 4 responden tetapi semua responden tidak memiliki tabungan. Hal ini berarti dengan pendapatan dari pengolahan ikan asin kurang memberikan dampak pada tabungan responden.

\section{KESIMPULAN}

Berdasarkan hasil analisis penelitian dan pembahasan yang telah diuraikan pada bab sebelumnya, maka dapat ditarik kesimpulan bahwa dengan adanya pengolahan ikan asin, pendapatan buruh pengolah ikan asin sedikit meningkat, sehingga kehidupan buruh pengolah ikan asin ini terbantu secara ekonomi seperti dapat makan tiga kali sehari, dan membeli pakaian walaupun setahun sekali. Buruh pengolah ikan asin dapat dikategorikan belum sejahtera, namun secara ekonomi buruh pengolah ikan asin sangat terbantu, jika sebelum bekerja di pengolahan ikan asin, buruh pengolah ikan asin hanya dapat makan satu kali sehari namun setelah bekerja di pengolahan ikan asin buruh pengolah ikan asin dapat makan tiga kali sehari, membeli minimal satu stel pakaian, memperbaiki dinding rumah yang sudah rusak. Untuk penelitian selanjutnta diharapkan dapat mengkaji lebih luas lagi terkait bisnisnya.

\section{PUSTAKA ACUAN}

Anwar Khairul. Etika Bisnis. Jakarta: Gramedia Pustaka Utama. 2013

Adawyah, Rabiatul. (2008). Pengolahan dan Pengawetan Ikan, Edisi Pertama. Jakarta: Bumi Aksara.

Arikunto, Suharsimi. (2006). Prosedur Penelitian Suatu Pendekatan Praktik Jakarta : Rineka Cipta.

Basri, Ikhwan Abidin. (2015).Islam dan Pembngunan Ekonomi,Jakarta : Gema Insani Press.

Fahrizal. (2010). Peningkatan Mutu Ikan Teri Asin Kering Di Aceh Besar, Aceh. Skripsi yang tidak diterbitkan, Universitas Syaiah Kuala.

Fahrudin, Adi. (2012). Pengantar Kesejahteraan Sosial. Bandung: PT Refika Aditama. Ismail,Asep Usman. (2012).Al-Qur'an Dan Kesejahteraan Sosial,Tangerang: Lentera Hati.

Junaidi, Edi. (2019). Ekonomi Mikro. Yogyakarta: Deepublish.

Manurung, Dimas. (2017).Ekonomi Mikro dan Makro. Jakarta: Grasindo. 
Jurnal Investasi Islam

Vol. 6 No. 2, Desember $2021: 160-172$

Qardahawi, Yusuf . (2001).Peran Nilai Dan Moral Dalam Perekonomian Islam,Jakarta: Rabbani Pers.

Rahardja. (2018). Pengantar Ekonomi dan Bisnis. Jakarta: Gramedia.

Swastha. (2019). Bisnis dan Penerapannya di Era Milineal,Jakarta: Grasindo.

Suwiknyo Dwi. ( 2009). Kamus Lengkap Ekonomi Islam. Yogyakarta: Total Media.

Sugiyono, (2009). Metode Penelitian Kuantitatif, Kualitatif, dan R\&D. Bandung: Alfabeta.

Syamsudin, Vismaia, dkk. (2009). Metodelogi Penelitian Pendidikan Bahasa. Bandung: PT Remaja Rosdakarya.

Ustami, Tri. (2016). Etika Bisnis. Bandung: Pusaka Media. 